\title{
RPE cell line as a useful in vitro model for studying retinoic acid receptor beta: expression and affinity.
}

Barbara Pavan ${ }^{*}$, Alessandro Dalpiaz ${ }^{\dagger}$, Carla Biondi ${ }^{* 1}$, Marzia Nieddu*, Antonella De Luca ${ }^{\ddagger}$, Puttur D. Prasad ${ }^{\S}$, Guglielmo Paganetto and Bartolo Favaloro".

* University of Ferrara, Dept of Biology, General Physiology sect., via L. Borsari, 46 - 44100 Ferrara, Italy.

${ }^{\dagger}$ University of Ferrara, Dept of Pharmaceutical Sciences, via Fossato di Mortara, 19 - 44100 Ferrara, Italy.

*Department of Biomedical Sciences, University of Chieti "G. D'Annunzio" School of Medicine, and Unit of Gene Regulation, Center of Excellence on Aging, "G. D'Annunzio" University Foundation, Chieti, Italy

$\S$ Department of Biochemistry \& Molecular Biology - Medical College of Georgia, Augusta, GA 30912-2100.

SISTA - Servizio Igiene Sicurezza e Tutela Ambientale, via Fossato di Mortara 17/19, 44100 Ferrara, Italy

${ }^{1}$ To whom correspondence should be addressed, at University of Ferrara, Dept. of Biology, General Physiology sect., via L. Borsari, 46 - 44100 Ferrara, Italy; phone: +39 0532 455482; fax: +39 0532 207143; e-mail: clm@unife.it

Short title: HRPE cells as in vitro model to study RAR- $\beta$ expression and affinity. 


\section{SUMMARY}

Retinoids mediate their biological effect by interacting with specific nuclear receptors. Of the several known retinoic acid receptor subtypes, RAR $\beta$ is of particular interest since its expression is silenced in many cancers and is believed to be a tumor suppressor. Specific ligands of RAR $\beta$ can potentially be used in anti-cancer therapy. Here we have investigated the feasibility of using HRPE cells as an experimental model for characterizing RAR $\beta$-ligand interaction. RT-PCR and western blot analyses show that HRPE cells specifically express only RAR $\beta$ and none of the other receptor subtypes. In addition, our studies show that the expression of RAR $\beta$ increases with increasing passage number of the cells. Interestingly, the increase in RAR $\beta$ expression is not associated with shortening of the telomere length, a typical biomarker of cellular senescence. We also describe here a protocol to characterize RAR $\beta$-ligand interaction using nuclear extract from late passage HRPE cells as the source of endogenous RAR $\beta$. Using $\left[{ }^{3} \mathrm{H}\right] \mathrm{CD} 367$ as the ligand, RAR $\beta$ in HRPE cells showed an affinity of $9.6 \pm 0.6 \mathrm{nM}$ and a $\mathrm{B}_{\max }$ of $780 \pm 14 \mathrm{fmol} / \mathrm{mg}$ protein. We have confirmed the feasibility of using this assay to detect interaction of ligands with RAR $\beta$ by investigating the ability of certain flavonoids to inhibit the binding of $\left[{ }^{3} \mathrm{H}\right] \mathrm{CD} 367$ to HRPE cell nuclear extract. The inhibition constant of the flavonoids for RAR $\beta$ ranged between $\sim 1-30 \mu \mathrm{M}$, showing that the flavonoids interact with RAR $\beta$ with low affinity.

Key Words: RAR $\beta$, HRPE cells, $\left[{ }^{3} \mathrm{H}\right] \mathrm{CD} 367$, senescence, telomere, culture passage. 


\section{INTRODUCTION}

Retinoic acid (RA) and its natural derivatives (retinoids) are important vitamin A metabolites that regulate cellular growth and differentiation [1]. Intracellularly, RA specifically interacts with two distinct types of proteins. In the cytoplasm, RA interacts with cytosolic retinoic acid binding proteins (CRABPs), which are primarily involved in the storage, intracellular transport, and metabolism of retinoic acid [2]. In the nucleus, RA interacts with nuclear retinoic acid receptors, which are proteins that function as ligand-dependent transcription factors that are related to the steroid and thyroid hormone receptor family [3]. Upon ligand binding, the receptors are activated and induce the transcription of target genes by binding to RA-responsive elements (RARE) in the promoter regions. There are two distinct classes of nuclear retinoic acid receptors: the Retinoic Acid Receptor (RAR or NR1A) and the Retinoid X Receptor (RXR or NR2B), [2, 4]. Both RAR and RXR have three subtypes, $\alpha, \beta$, and $\gamma$ that are encoded by separate genes located at distinct chromosomal loci [5]. The nuclear retinoic acid receptor subtypes are differentially expressed both spatially as well as temporally $[5,6,7]$. In humans, RAR $\alpha$ is expressed in most tissues, RAR $\beta$ mainly in neural tissues with limited expression in skin, RAR $\gamma$ is expressed predominantly in skin, $\mathrm{RXR} \alpha$, in liver, kidney, spleen, and skin, $\mathrm{RXR} \beta$ in almost all tissues and $\mathrm{RXR} \gamma$ expression in mostly muscle and brain.

Among the nuclear retinoic acid receptors, the RAR $\beta$ gene is of particular interest to cancer biologists because it regulates metabolic pathways associated with tumor-suppressive effects mediated by retinoids $[8,9]$. The RAR $\beta$ gene contains a RARE and thus the expression of RAR $\beta$ is regulated by RA. Though loss of expression of several of the nuclear retinoid receptors has been detected in various cancer cell lines, loss of RAR $\beta$ is the most common in a variety of cancer, including that of head and neck, breast, lung, esophagus, pancreas, cervix and prostate, and its expression correlates inversely with cancer progression and tumor grade [10]. Epigenetic modifications of the RAR $\beta$ promoter has been linked to the loss of RAR $\beta$ expression in cancer cells [9]. Recent studies by Geisen et al $[8,11]$ have shown that RAR $\beta$ may have a role to play in cellular senescence as well. They observed that both basal and RA-induced RAR $\beta$ mRNA levels in normal cells tend to increase with senescence. Similar observation was made by Lee and cowokers in aging fibroblasts with decreased proliferative capacity, who observed a selective up-regulation of RAR $\beta$ expression in response to RA and its derivatives in these cells [12]. This suggests that genetic events important in regulating cellular senescence may also play a significant role in tumor suppression in humans. Indeed, RAR $\beta$ expression is up-regulated with serial passage in senescing normal mammary epithelial cells while it is down-regulated in mammary cancer cell lines [1]. RAR $\beta$, therefore, is of great interest as a potential target in the design of anti-tumoral drugs and to study the mechanisms of their effects [9]. Availability of a standardized and sensitive method to characterize ligand binding specifically to RAR $\beta$ would therefore be of great utility. However, the accuracy and reproducibility of different methods for studying binding affinities of specific compound to RARs can be compromised by several factors which can be summarized as (i) a low abundance of RARs in natural cells and tissues resulting in a low ratio of specific versus nonspecific binding sites; (ii) the chemical instability of the natural ligand, RA; and (iii) the difficulty of designing a perfect method to separate free from bound ligand [13].

We report here an effective method to perform RAR $\beta$-specific ligand binding studies using human retinal pigment epithelial (HRPE) cells which overcomes most of the drawbacks listed above. Since retinal pigment epithelial cells perform a number of physiological functions essential for vision, namely the uptake, processing, transport and release of vitamin A (retinol) and its visual cycle intermediates retinoids [14], we first investigated the expression of retinoid receptors in HRPE cells. Results presented here show for the first time that HRPE cells natively and selectively express appreciable levels of only RAR $\beta$. We also provide evidence to show that RAR $\beta$ expression in these cells increases with increasing passage of the cells. We have next standardized a RAR $\beta$ 
receptor assay using nuclear extracts from late passage HRPE cells and $\left.{ }^{3} \mathrm{H}\right] \mathrm{CD} 367$, a stable synthetic ligand for the RAR subtypes [15]. The efficacy of our method allowed us to distinguish between different levels of native RAR $\beta$ expression in serially passaged of HRPE cells and characterize the affinity of several flavonoids to RAR $\beta$.

\section{EXPERIMENTAL}

\section{Materials}

$\left[{ }^{3} \mathrm{H}\right] \mathrm{CD} 367$ (specific activity $42 \mathrm{Ci} / \mathrm{mmol}$ ) and CD367 were kindly provided by GALDERMA (Sophia Antipolis, France). $\left[{ }^{3} \mathrm{H}\right] 9$-cis-RA (specific activity $43.0 \mathrm{Ci} / \mathrm{mmol}$ ) was obtained from Amersham Life Sciences (Milan, Italy). 9-cis-RA, genistein, quercetin, daidzein, equol, dithiothreitol (DTT), dextran, bovine serum albumin (BSA), diethyl-pyrocarbonate (DEPC) and the protease inhibitors phenylmethylsulfonyl fluoride, aprotinin and leupeptin were purchased from Sigma (Milan, Italy). Glycerol, thioglycerol, isopropyl alcohol and activated charcoal were obtained from Merck (Milan, Italy). All tissue culture media, fetal bovine serum and RT-PCR reagents were purchased from Invitrogen (Milan, Italy).

\section{HRPE cell culture}

The human retinal pigment epithelial (HRPE) cell line was routinely grown at $37{ }^{\circ} \mathrm{C}$ in an atmosphere of $5 \% \mathrm{CO}_{2} / 95 \%$ air, in a mixture of Ham's $\mathrm{F} 12$ and Dulbecco's modified Eagle medium (F12/DMEM) (1:1 vol/vol) supplemented with $10 \%$ fetal bovine serum (10\% FBS), 100 $\mu \mathrm{g} / \mathrm{ml}$ streptomycin, and $10 \mathrm{IU} / \mathrm{ml}$ penicillin. The population doubling time was 24 hours. Cells were seeded every 4 to 5 days by trypsin-EDTA dispersion and grown to confluence. Early and late passage HRPE were defined here as those cultures receiving less than 5 trypsin passages and more than 35 trypsin passages, respectively.

\section{Semi-quantitative RT-PCR}

Total RNA was isolated from HRPE cells using Trizol reagent $\left(1 \mathrm{ml}\right.$ reagent $/ 10^{6}$ cells $)$ following the manufacturer's instructions. Total RNA was treated with DNase I (Invitrogen, Milan, Italy) and used in oligo(dT)-primed first strand cDNA synthesis (SuperScript II RT, Invitrogen, Milan, Italy). Primers and PCR conditions for the different RARs used are presented in Table 1. Relative amount of the mRNA of RAR was determined by semi-quantitative RT-PCR as described before [16]. The PCR products were resolved in 1.5\% agarose gel containing ethidium bromide and the intensity of the cDNA bands relative to background was determined using Quantity One system (BioRad, Milan, Italy). The linear range of PCR was empirically determined in initial experiments where by PCR was set up with each primer set with different number of amplification cycles (15 to 40 cycles). The relationship between the intensity of the signal and the PCR cycle number was analyzed to determine the linear range for the PCR product formation. The intensities of the signals within the linear range were used for data analysis. The RAR $\beta$ amplified linearly between cycles 28 to 34 . When quantitative RT-PCR was performed, the housekeeping gene 18S rRNA (linear amplification between 18 to 22 cycles) was amplified simultaneously, its specific primers being added to the PCR reaction after the first 10 cycles and used for normalization of target gene values throughout experiments because its level did not vary significantly in relation to passage number [16]. Under the PCR conditions described above, the amount of PCR product obtained showed a linear correlation with the amount of cDNA added to the PCR mixture, i.e., ratios of RAR $\beta$ mRNA to $18 \mathrm{~S}$ mRNA remained almost constant. In each PCR reaction, -RT (to rule out amplification of genomic DNA) and DEPC-treated water instead of cDNA were used as negative controls. 


\section{Western blot analysis}

Protein extracts were obtained from $80 \%$ confluent HRPE cells at early and late passages, using Passive Lysis Buffer (Promega). Crude extracts $(40 \mu \mathrm{g})$ were analysed by SDS/PAGE on $12.5 \%(\mathrm{w} / \mathrm{v})$ polyacrylamide gels. Proteins were transferred electrophoretically to nitrocellulose filter (for $120 \mathrm{~min}$ at $0.3 \mathrm{~A}$ ) using an immunoblot transfer apparatus (Bio-Rad). After transfer, the filter was incubated for $180 \mathrm{~min}$ at room temperature in $10 \%(\mathrm{w} / \mathrm{v})$ non fat milk in Tris-buffered saline (TBS; $500 \mathrm{mM} \mathrm{NaCl}$ and $20 \mathrm{mM}$ Tris/HCl, $\mathrm{pH} 7.5$ ), supplemented with $0.05 \%$ (v/v) Tween20 to block non-specific binding. The blot was incubated overnight at $4{ }^{\circ} \mathrm{C}$ with $10 \%$ non fat milk in TBS, supplemented with $0.05 \%(\mathrm{v} / \mathrm{v})$ Tween-20, containing rabbit polyclonal anti-RAR $\beta$ (Santa Cruz Biotechnology) at a dilution of 1:1000. After three washes with TBS containing $0.05 \%(\mathrm{v} / \mathrm{v})$ Tween-20, the blot was incubated for $60 \mathrm{~min}$ at room temperature with peroxidase-conjugated goat anti-rabbit immunoglobulin (Calbiochem) diluted at 1:2000 in 10\% non fat milk in TBS, supplemented with $0.05 \%(\mathrm{v} / \mathrm{v})$ Tween-20. The blot was again washed three times with TBS containing $0.05 \%(\mathrm{v} / \mathrm{v})$ Tween-20. Antibodies were visualized using a chemiluminescence detection system (Western Blotting Luminol Reagent, Santa Cruz Biotechnology).

\section{Telomere length}

Genomic DNA from HRPE cells was isolated using Wizard genomic DNA purification kit (Promega). Telomere length comparisons were done using the Telo TAGGG Telomere Length Assay kit (Roche Diagnostics, Mannheim, Germany). Genomic DNA (2 $\mu \mathrm{g})$ was digested with RsaI and HinfI restriction enzymes, size-fractionated on a $0.8 \% \mathrm{w} / \mathrm{v}$ agarose gel, and transferred to nylon membranes in $20 \times$ SSC by capillary blotting. Controls were digoxigenin- (DIG) labelled DNA molecular weight markers, and high and low molecular weight un-labelled DNA markers. The blotted DNA fragments were hybridized to a DIG-labelled TTAGGG probe and incubated with DIG-specific antibody covalently coupled to alkaline phosphatase. The immobilised telomere probe was visualized using CDP-Star, a highly sensitive chemiluminescence substrate of alkaline phosphatase. Blots were documented and analysed with the GelDoc imaging system and the Quantity One software from BioRad (München, Germany). The mean length of the telomere restriction fragment was calculated according to the manufacturers instructions (Telo TAGGG telomere length assay).

\section{Preparation of cytosolic and nuclear extracts}

The preparation of nuclear and cytosolic extracts was based on the procedure described by Nervi et al. [17], with several modifications. Briefly, HRPE cells $\left(\sim 1-5 \times 10^{8}\right)$ from 10-15 confluent 150 $\mathrm{cm}^{2}$ tissue culture dishes at $35^{\text {th }}$ or higher passage were trypsinized and collected in growth medium by centrifugation at $1000 \mathrm{~g}$ for $5 \mathrm{~min}$ and cell pellet was rinsed twice with ice-cold phosphatebuffered saline (PBS) containing $2 \mathrm{mM}$ EDTA. Pellet was then resuspended in $3 \mathrm{ml}$ of ice-cold lysis buffer (10 mM Tris-HCl, $1.5 \mathrm{mM}$ EDTA, $1 \mathrm{mM}$ DTT, 10\% v/v glycerol, $\mathrm{pH} 7.6)$ in the presence of protease inhibitors $(1 \mathrm{mM}$ phenylmethylsulfonyl fluoride, $20 \mu \mathrm{g} / \mathrm{ml}$ aprotinin and 20 $\mu \mathrm{g} / \mathrm{ml}$ leupeptin) and placed on ice for $15 \mathrm{~min}$. Cells were then homogenized with a glass Dounce homogenizer (pestle B, 60-90 strokes) and the homogenate was centrifuged at $4^{\circ} \mathrm{C}$ for $30 \mathrm{~min}$ at $100000 \mathrm{~g}$. The resulting supernatant was the cytosolic extract. The pellet, containing the nuclei, was resuspended in a volume equal to $2 / 3$ the cell pellet volume of extraction buffer $(10 \mathrm{mM}$ Tris- $\mathrm{HCl}$, $1.5 \mathrm{mM}$ EDTA, $1 \mathrm{mM}$ DTT, $10 \mathrm{mM}$ thioglycerol, $0.8 \mathrm{M} \mathrm{KCl}, 10 \% \mathrm{v} / \mathrm{v}$ glycerol, $\mathrm{pH} 8.00$ ) containing the protease inhibitors. The suspension was incubated for $1 \mathrm{hr}$ on ice with repeated resuspension every $10 \mathrm{~min}$, rehomogenized with Dounce homogenizer (pestle B) and then centrifuged at $100000 \mathrm{~g}$ for 1 hour at $4^{\circ} \mathrm{C}$. The resulting supernatant was referred to as the nuclear extract. Both cytosolic and nuclear extracts were used either immediately or after storage at $-80^{\circ} \mathrm{C}$ and aliquots of both were assayed for protein concentration according to Lowry et al. [18] with BSA as standard. 


\section{Dextran-charcoal adsorption binding assay}

Nuclear or cytosolic extracts containing $200 \mu \mathrm{g}$ of proteins were incubated in $200 \mu \mathrm{l}$ of 20 $\mathrm{mM}$ Tris- $\mathrm{HCl}, 150 \mathrm{mM} \mathrm{NaCl}, 1 \mathrm{mM}$ DTT, $\mathrm{pH} 8.00$ at $4^{\circ} \mathrm{C}$ for 4 hours. Saturation experiments were carried out using 10 different concentrations of $\left[{ }^{3} \mathrm{H}\right] \mathrm{CD} 367$ ranging from 1 to $80 \mathrm{nM}$. Displacement experiments were performed using nine different concentrations of cold drug in the presence of 10 $\mathrm{nM}\left[{ }^{3} \mathrm{H}\right] \mathrm{CD} 367$. Binding assays with $\left[{ }^{3} \mathrm{H}\right] 9$-cis-RA were done at a final concentration of $10 \mathrm{nM}$. Nonspecific binding was measured in the presence of 200-fold excess of unlabeled CD367 or 9-cisRA. Separation of bound from free radioligand was performed essentially as previously described by Sablonnière et al [13]. Briefly, $100 \mu \mathrm{l}$ of ice-cold charcoal/dextran suspension (3\% water-washed activated charcoal Merk $/ 0.3 \%$ dextran in $20 \mathrm{mM}$ Tris-HCl, $1 \mathrm{mM}$ EDTA, $1 \mathrm{mM}$ DTT, $0.1 \%$ BSA, $\mathrm{pH} 8.00$ ) were added to the incubation mixture. After $10 \mathrm{~min}$ of incubation at $4^{\circ} \mathrm{C}$, the samples were centrifuged at $6000 \mathrm{~g}$ for $5 \mathrm{~min}$ and $150 \mu \mathrm{l}$ of clear supernatant was counted for radioactivity. In all assays, total bound radioligand never exceeded $10 \%$ of the radioligand added. The percent of specific binding was $\sim 53 \%$ and $\sim 35 \%$ of the total bound radioactivity for $\left[{ }^{3} \mathrm{H}\right] \mathrm{CD} 367$ and $\left[{ }^{3} \mathrm{H}\right] 9$-cisRA, respectively. Saturation experiments data $\left(\mathrm{K}_{\mathrm{D}}\right.$ and $\mathrm{B}_{\max }$ values) were obtained by computer analysis of saturation curves. Linear regression of Scatchard plot was performed according to the equation [Bound] $/\left[\right.$ Free] $=\mathrm{B}_{\max } \mathrm{K}_{\mathrm{A}}-\mathrm{K}_{\mathrm{A}}$ [Bound], were $\mathrm{K}_{\mathrm{A}}$ is $1 / \mathrm{K}_{\mathrm{D}}$ and [Bound] are the specific binding values of the radiolabelled ligand obtained at the [Free] incubation concentrations. The concentrations of the unlabelled drugs needed to displace $50 \%$ of the bound radioligand $\left(\mathrm{IC}_{50}\right)$ values were obtained by non-linear regression analysis of the displacement curves. Inhibitory binding constants $\left(\mathrm{K}_{\mathrm{i}}\right.$ values) were calculated from the $\mathrm{IC}_{50}$ values according to the Cheng and Prusoff [19] equation $\mathrm{K}_{\mathrm{i}}=\mathrm{IC}_{50} /\left(1+\left[\mathrm{C}^{*}\right] / \mathrm{K}_{\mathrm{D}} *\right.$, where [C*] is the concentration of the radioligand and $\mathrm{K}_{\mathrm{D}}$ its dissociation constant. All binding data were analysed using the software Graph Pad Prism (Graph Pad, San Diego, CA, USA).

\section{Statistical analyses}

All values were expressed as means \pm S.E.M. Statistical significance was determined by $t$-test (Prism 4.0; GraphPad Software). $P$ values less than 0.05 were considered statistically significant.

\section{RESULTS AND DISCUSSION}

\section{Expression of RAR $\beta$ in HRPE celis}

Expression of the six nuclear retinoid receptor in HRPE cells was first investigated by RTPCR using previously validated primers $[14,20]$. Only RAR $\beta$-specific primers produced a $400 \mathrm{bp}$ amplification product of the expected size (Fig.1). Primer pairs specific for RAR $\alpha, \operatorname{RAR} \gamma, \operatorname{RXR} \alpha$, $\operatorname{RXR} \beta$ and RXR $\gamma$ did not yield any amplification product (data not shown), suggesting that only RAR $\beta$ is expressed in HRPE cells. As mentioned earlier, expression of nuclear retinoid receptors is not ubiquitous. For instance, hematopoietic cells have been reported to express exclusively RAR $\alpha$, whereas RAR $\beta$ transcripts are particularly abundant in brain and areas undergoing programmed cell death [6]. This intriguing phenomenon suggested that cell propagation conditions should be considered as significant variable influencing the biological behaviour. The replicative senescence of established cell lines had been well characterized [21]. Proteins which show a simple increase or a simple decrease may participate in a hypothetical mechanism of "biological clock" in the cultured cells [22]. At this regard, aging of RPE cells in vitro has been the subject of several studies. First of all, Wang et al. [23] examined changes in gene expression profiles of RPE normal cells, which were aged in vitro by repeated passage, but little information on the role in the aging process for most of the regulated genes was provided. Furthemore, it has been shown that in ARPE 19 cells, a 
spontaneously arising human RPE cell line, in normal cell culture conditions most of the retinoic acid receptors were expressed and RAR $\beta$ expression was modulated by a proliferative treatment [24].

Since previous studies have shown changes in the expression of RAR $\beta$ related to the passage number, we next evaluated the effect of passage number on RAR $\beta$ expression in HRPE cells. Towards this, we measured the steady-state levels of RAR $\beta$ mRNA in early and late passage HRPE cells by semi-quantitative RT-PCR. The transcription of RAR $\beta$ was significantly up-regulated in late passage HRPE cells compared to early passage HRPE cells (Fig. 2). The expression of RAR $\beta$ was also confirmed by immunoblot analysis using an anti-RAR $\beta$ serum as described in the Materials and Methods section (Fig. 3). Crude extracts of HRPE cells obtained from $5^{\text {th }}$ and $35^{\text {th }}$ passage analyzed for RAR $\beta$ expression showed an increase in the expression levels of RAR $\beta$ in extracts from the $35^{\text {th }}$ passage, compared to that obtained from the $5^{\text {th }}$ passage. Thus, the increased level of the RAR $\beta$ observed by western blot analysis in late passage HRPE cells was consistent with increased levels of transcript detected by semi-quantitative RT-PCR in RNA isolated from corresponding cells.

\section{Effect of cell passage on telomere length}

The shortening of telomere has been proposed as the most probable mechanism of the cellular senescence by several Authors $[25,26]$, but not all phenotypes of the senescent cells could be ascribed to the shortening of telomere [27]. We next investigated the relationship between RAR $\beta$ expression and telomere length in HRPE cells. The effect of replicative aging of HRPE cells in multiple passaging was evaluated by telomere length assay at either early or late passages to determine telomeric DNA loss because of cell divisions in multiple passaging [28]. Figure 4 shows a representative autoradiograph of smears of genomic DNA isolated from early and late passage HRPE cells hybridized with DIG labelled Telo TAGGG probe. The HRPE cells showed a stabilized telomere at around $3.1 \mathrm{~kb}$ in both low and high passage cells, indicating that the length of the telomere is not affected by passage number in HRPE cells. When telomeres reach a critical shortening in length senescence is induced resulting into permanent proliferation arrest [29]. In our work, for the first time, a typical biomarker of cellular senescence such as RAR $\beta$ has been shown to be up-regulated by repeated passage in a well-established cell line. Furthermore, this up-regulation is not due to or associated with shortening of telomere. Taken together, these results suggest that the increase in RAR $\beta$ mRNA and protein levels detected in late passage HRPE cells does not appear to be due to a senescence condition.

\section{In vitro binding assay}

We first measured the specific binding of retinoic acid in cytosolic and nuclear extracts isolated from HRPE cells at $35^{\text {th }}$ or higher passage by performing assays with $10 \mathrm{nM}\left[{ }^{3} \mathrm{H}\right] 9$-cis-RA (agonist of both RAR and RXR subtypes) and saturation experiments (1-80 nM) of $\left.{ }^{3} \mathrm{H}\right] \mathrm{CD} 367$ (agonist of only RAR subtypes). No detectable binding was observed in cytosolic extracts using both the radioligands (data not shown). This could be explained assuming that HRPE cells do not contain detectable levels of cellular retinaldehyde binding protein (CRABP). Indeed, it was already reported that RPE cultures established from adult donors, maintained in DMEM with FBS on a tissue culture substrate, lose RPE specific properties such as pigmentation, expression of tyrosinase, CRABP and bestrophin [30]. Moreover, it was demonstrated that CRABP is expressed in the tissue of human adults, but not in the derived RPE cell lines [31]. Similar loss of CRABP was also reported to occur in HL-60 cells, where total RA-binding was found to be associated with the nuclear extract of which were found to contain only nuclear RAR $\alpha$ and no cytosolic binding proteins [17].

On the other hand, specific binding was observed with both $\left[{ }^{3} \mathrm{H}\right] 9$-cis-RA and $\left[{ }^{3} \mathrm{H}\right] \mathrm{CD} 367$. The specific bound observed for $\left[{ }^{3} \mathrm{H}\right] 9$-cis RA was $133 \pm 9 \mathrm{fmol} / \mathrm{mg}$ of protein (data not shown). 
Figure 5 shows the saturable binding of $\left[{ }^{3} \mathrm{H}\right] \mathrm{CD} 367$ to the late passage HRPE cell nuclear extract. Scatchard analysis (Fig.5, inset) of the data was linear in the concentration range investigated $(\mathrm{r}=$ 0.982, $\mathrm{p}<0.0001, \mathrm{n}=10)$ and, analogously, computer analysis of the saturation experiments suggested a one-site, rather than a two-sites binding model. The dissociation binding constant $\left(\mathrm{K}_{\mathrm{D}}\right)$ and $B_{\max }$ values derived from the saturation experiments of $\left[{ }^{3} \mathrm{H}\right] \mathrm{CD} 367$ were $9.6 \pm 0.6 \mathrm{nM}$ and 780 $\pm 14 \mathrm{fmol} / \mathrm{mg}$ of protein, respectively.

The binding data obtained with radiolabeled ligands corroborate the specific expression of RAR $\beta$ in HRPE cells. 9-cis RA is known to be a high affinity ligand of both RAR and RXR subtypes [32, 33]; on the other hand RT-PCR and Western blot data reported above show that HRPE cells selectively express the RAR $\beta$ subtype. Taking into account that CD367 is a relatively stable ligand and more specific to RAR subtype than $\left[{ }^{3} \mathrm{H}\right] 9$-cis RA [13], we have therefore chosen $\left[{ }^{3} \mathrm{H}\right] \mathrm{CD} 367$ to characterize the binding properties of nuclear RA receptors. The linearity of the Scatchard plot reported in Fig. 5 suggests that $\left[{ }^{3} \mathrm{H}\right] \mathrm{CD} 367$ is binding to only one RAR subtype in HRPE cell nuclear extract which, based on our RT-PCR and western blot results, is RAR $\beta$. The CD367 affinity $\left(K_{D}=9.6 \mathrm{nM}\right)$ found in HRPE cells appears in agreement with the values obtained by previous binding studies towards RAR receptors [15]. Furthermore, the $B_{\max }$ value found in HRPE cells $(\sim 800 \mathrm{fmol} / \mathrm{mg}$ of protein $)$ is in the same order of magnitude of that obtained in COS cells expressing RAR $\beta$ cDNA (900 fmol/mg protein) [15]. We have performed the binding studies on nuclear extracts of HRPE cells at $35^{\text {th }}$ or higher passage, when the cells show a significant upregulation of RAR $\beta$ as demonstrated by RT-PCR (Fig. 2) and Western blot analysis (Fig. 3), respectively. Taken collectively, our results indicate that HRPE cell is a good model of an established cell line for characterizing RAR $\beta$ ligand specificity. Since the expression of RAR $\beta$ increase with increasing passage of the cells, the problem of poorly detectable RAR $\beta$ in native cells can be overcome by using late passage HRPE cells instead of overexpressing RAR $\beta$ by recombinant techniques.

To confirm the feasibility of using HRPE cells in characterizing RAR $\beta$ ligands, we have measured the affinity of several flavonoids to RAR $\beta$. We chose these compounds because of their xenoestrogenic properties and their presence in natural food sources. Retinoids are considered to be agents of chemoprevention and differentiation in several proliferative diseases, including benign and malignant breast diseases. Knowledge of how retinoids interrupt proliferative processes pharmacologically or through diet, and how they induce differentiation and programmed cell death, will probably lead to new treatment strategies, especially in the prevention of breast cancer [20]. Therefore, to investigate the interaction of flavonoids with RAR $\beta$, we studied the effect of these flavonoids on the binding of $\left.{ }^{3} \mathrm{H}\right] \mathrm{CD} 367$ to nuclear extracts of HRPE cells (Fig. 6). The results obtained suggest flavonoids do interact with RAR $\beta$, however, only weakly. The $\mathrm{K}_{\mathrm{i}}$ values obtained from the analysis of the curves are presented in Table 2 . It can be observed that the RA affinity for RAR $\beta$ was in the nanomolar range $(9.1 \pm 0.6 \mathrm{nM})$ whereas the binding of the flavonoids was relatively weak, with $K_{i}$ values ranging from $0.9 \pm 0.5 \mu \mathrm{M}$ to $30 \pm 2 \mu \mathrm{M}$, and thus may not be able to significantly interfere with the endogenous activity of RAR $\beta$. But, what is important is that the methodology that we report here can be utilized to characterize even the relatively weak interaction between flavonoids and RAR $\beta$.

In conclusion, we report here on the specific expression of RAR $\beta$ in HRPE cells, and this expression increases with increasing passage of the cells. The increased RAR $\beta$ expression in aging cells is not associated with decrease in telomere length. We also show that the increased expression in high passage cells can be exploited to develop a specific assay to characterize RAR $\beta$-ligand interactions.

\section{Acknowledgments}

This research was supported by the University of Ferrara and of Chieti research grants (C. Biondi and B. Favaloro). 


\section{REFERENCES}

1. Swisshelm, K., Ryan, K., Lee, X., Tsou, H.C., Peacocke, M., Sager, R. (1994) Downregulation of retinoic acid receptor beta in mammary carcinoma cell lines and its upregulation in senescing normal mammary epithelial cells. Cell Growth Differ. 5, 133-141.

2. Si, S.P., Tsou, H.C., Lee, X., Peacocke, M. (1995) Effect of cellular senescence and retinoic acid on the expression of cellular retinoic acid binding proteins in skin fibroblasts. Exp. Cell Res. 219, 243-248.

3. Gronemeyer, H., Gustafsson, J.A., Laudet, V. (2004) Principles for modulation of the nuclear receptor superfamily. Nat. Rev. Drug Discov. 3, 950-964.

4. Greiner, E.F., Kirfel, J., Greschik, H., Huang, D., Becker, P., Kapfhammer, J.P., Schüle, R. (2000) Differential ligand-dependent protein-protein interactions between nuclear receptors and a neuronal-specific cofactor. Proc. Natl. Acad. Sci. U S A. 97, 7160-7165.

5. Chambon, P. (1996) A decade of molecular biology of retinoic acid receptors. FASEB J. 10, 940-954.

6. Dollè, P., Ruberte, E., Kastner, P., Petkovich, M., Stoner, C.M., Gudas, L.J., Chambon, P. (1989) Differential expression of genes encoding alpha, beta, and gamma retinoic receptors and CRABP in the developing limbs of the mouse. Nature (Lond.) 342, 702-705.

7. Mangelsdorf, D.J., Thummel, C., Beato, M., Herrlich, P., Schütz, G., Umesono, K., Blumberg, B., Kastner, P., Mark, M., Chambon, P., Evans, R.M. (1995) The nuclear receptor superfamily: the second decade. Cell. 83, 835-839.

8. Geisen, C., Denk, C., Gremm, B., Baust, C., Karger, A., Bollag, W., Schwarz, E. (1997) High-level expression of the retinoic acid receptor beta gene in normal cells of the uterine cervix is regulated by the retinoic acid receptor alpha and is abnormally down-regulated in cervical carcinoma cells, Cancer Res. 57, 1460-1467.

9. Pavan, B., Biondi, C., Dalpiaz, A. (2006) Nuclear retinoic acid receptor beta as a tool in chemoprevention trials. Curr. Med. Chem. 13, 3553-3563.

10. Xu, X.C. (2007) Tumor-suppressive activity of retinoic acid receptor-beta in cancer. Cancer Lett. 253, 14-24.

11. Geisen, C., Denk, C., Küpper, J.H., Schwarz, E. (2000) Growth inhibition of cervical cancer cells by the human retinoic acid receptor beta gene. Int. J. Cancer 85, 289-295.

12. Lee, X., Si, S.P., Tsou, H.C., Peacocke, M. (1995) Cellular aging and transformation suppression: a role for retinoic acid receptor beta. Exp. Cell Res. 218, 296-304.

13. Sablonnière, B., Dallery, N., Grillier, I., Formstecher, P., Dautrevaux, M. (1994) Physicochemical parameters affecting the charcoal adsorption assay for quantitative retinoid-binding measurement. Anal. Biochem. 217, 110-118.

14. Janssen, J.J.M., Kuhlmann, E.D., van Vugt, A.H.M., Winkens, H.J., Janssen, B.P.M., Deutman, A.F., Driessen, C.A.G.G. (1999) Retinoic acid receptors and retinoic X receptors in the mature retina: Subtype determination and cellular distribution. Curr. Eye Res. 19, 338-347.

15. Delescluse, C., Cavey, M.T., Martin, B., Bernard, B.A., Reichert, U., Maignan, J., Darmon, M., Shroot, B. (1990) Selective high affinity retinoic acid receptor a or b-g ligands. Mol. Pharmacol. 40, 556-562.

16. Pavan, B., Frigato, E., Pozzati, S., Prasad, P.D., Bertolucci, C., Biondi, C. (2006) Circadian clocks regulate adenylyl cyclase activity rhythms in human RPE cells. Biochem. Biophys. Res. Commun. 350, 169-173.

17. Nervi, C., Grippo, J.F., Sherman, M.I., George, M.D., Jetten, A.M. (1989) Identification and characterization of nuclear retinoic acid-binding activity in human myeloblastic leukemia HL-60 cells. Proc. Natl. Acad. Sci. USA 86, 5854-5858.

18. Lowry, O.H., Rosenbrough, N.J., Farr, A.L., Randall, R.J. (1951) Protein measurement with the folin reagent. J. Biol. Chem. 193, 255-265. 
19. Cheng, Y. and Prusoff, W.H. (1973) Relationship between the inhibition constant (K1) and the concentration of inhibitor which causes 50 per cent inhibition $\left(\mathrm{I}_{50}\right)$ of an enzymatic reaction. Biochem. Pharmacol. 22, 3099-3108.

20. Pasquali, D., Bellastella, A., Valente, A., Botti, G., Papasso, I., del Vecchio, S., Salvatore, M., Colantuoni, V., Sinisi, A.A. (1997) Retinoic acid receptors $\alpha, \beta$, $\gamma$, and cellular retinol binding protein-I expression in breast fibrocystic disease and cancer. Eur. J. Endocrinol. 137, 410-414.

21. Matsuo, M., Kaji, K., Utakoji, T., Hosoda, K. (1982) Ploidy of human embryonic fibroblasts during in vitro aging. J. Gerontol. 37, 33-37.

22. Toda, T., Kaji, K., Kimura, N. (1998) TMIG-2DPAGE: a new concept of two-dimensional gel protein database for research on aging. Electrophoresis 19, 344-348.

23. Wang, X-F, Cui, J.Z., Nie, W., Prasad, S.S., Matsubara, J.A. (2004) Differential gene expression of early and late passage retinal pigment epithelial cells. Exp. Eye Res. 79, 209221.

24. Tombran-Tink, J., Lara, N., Apricio, S.E., Potluri, P., Gee, S., Ma, J.X., Chader, G., Barnstable, C.J. (2004) Retinoic acid and dexamethasone regulate the expression of PEDF in retinal and endothelial cells. Exp. Eye Res. 78, 945-955.

25. Harley, C.B., Vaziri, H., Counter, C.M., Allsopp, R.C. (1992) The telomere hypothesis of cellular aging. Exp. Gerontol. 27, 375-382.

26. Matsunaga, H., Handa, J.T., Aotaki-Keen, A., Sherwood, S.W., West, M.D., Hjelmeland, L.M. (1999) Beta-galactosidase histochemistry and telomere loss in senescent retinal pigment epithelial cells. Invest. Ophthalmol.Vis. Sci. 40, 197-202.

27. Sherr, C.J. and DePinho, R.A. (2000) Cellular senescence: mitotic clock or culture shock? Cell 102, 407-410.

28. Velicescu, M., Herbert, J., Yu, B., Shay, J.W., Granada, E., Dubeau, L. (2003) Aneuploidy and telomere attrition are independent determinants of crisis in SV40 transformed epithelial cells. Cancer Res. 63, 5813-5820.

29. Allsopp, R.C., Vaziri, H., Patterson, S., Goldstein, E.V., Younglai, A., Futcher, B. (1992) Telomere length predicts replicative capacity of human fibroblast. Proc. Natl. Acad. Sci. USA 89, 10114-10118.

30. Campochiaro, P.A. and Hackett, S.F. (1993) Corneal endothelial cell matrix promotes expression of differentiated features of retinal pigmented epithelial cells: implication of laminin and basic fibroblast growth factor as active components. Exp. Eye Res. 57, 539547.

31. Dunn, K.C., Aotaki-Keen, A.E., Putkey, F.R., Hjelmeland, L.M.. (1996) ARPE-19, a human retinal pigment epithelial cell line with differentiated properties. Exp. Eye Res. 62, 155-169.

32. Allenby, G., Bocquel, M.T., Saunders, M., Kazmer, S., Speck, J., Rosenberger, M., Lovey, A., Kastner, P., Grippo, J.F., Chambon, P.,. Levin, A.A. (1993) Retinoic acid receptors and retinoid $\mathrm{X}$ receptors: interactions with endogenous retinoic acids. Proc. Natl. Acad. Sci. USA 90, 30-34.

33. Yang, Y., Minucci, S., Ozato, K., Heyman, R.A., Ashwell, J.D. (1995) Efficient inhibition of activation-induced fas ligand up-regulation and $\mathrm{T}$ cell apoptosis by retinoids requires occupancy of both retinoid $\mathrm{X}$ receptors and retinoic acid receptors. J. Biol. Chem. 270, 18672-18677. 


\section{FIGURE LEGENDS}

Figure. 1. RT-PCR of RAR $\beta$ isoform expression relative to the constitutive gene $18 \mathrm{~S}$. Total RNA was reverse-transcribed followed by 35 -cycle PCR of cDNA using the primers described in Table 1. The RNA samples used were obtained from HRPE cells at the $35^{\text {th }}$ passage.

Figure 2. Semi-quantitative RT-PCR of RAR $\beta$. cDNA of RAR $\beta$ and the constitutive gene $18 \mathrm{~S}$ rRNA, derived from HRPE cells at $5^{\text {th }}$ and $35^{\text {th }}$ passage, were co-amplificated by semi-quantitative RT-PCR. (A) Intensity of RAR $\beta$ transcript is higher in HRPE cells at $35^{\text {th }}$ passage. (B) RAR $\beta$ mRNA expression was normalized on the basis of 18S RNA expression. RAR $\beta$ mRNA normalized with 18S RNA in separated and co-amplificated RT-PCR was represented.

Mean \pm SEM at $5^{\text {th }}$ and $35^{\text {th }}$ passage obtained in three independent experiments is shown.

$* \mathrm{P}<0.001$.

Figure 3. Immunoblotting of HRPE extracts with a rabbit polyclonal anti-RAR $\beta$ antibody. The RAR protein levels in HRPE cells were analysed using Chemi Doc System (Bio-Rad) and normalized to $\beta$-actin signal intensities of the corresponding lanes.

Values are reported as mean \pm S.D. of at least three different immunoblotting experiments.

$* \mathrm{P}<0.001$.

Figure 4. Telomere length inHRPE cells compared at $5^{\text {th }}$ and $35^{\text {th }}$ passage. Telomere length comparisons was done using the Telo TAGGG Telomere Length Assay kit (Roche Diagnostics, Mannheim, Germany). The signal intensities show the size distribution of terminal restriction fragments.

M, marker in kbp; lane 1, DNA from HRPE cells passage 5; lane 2, DNA from HRPE cells passage 35; lane 3, control, low molecular weight DNA; lane 4, control, high molecular weight DNA.

Figure 5. Saturation curve and its Scatchard plot (bound/free versus bound, inset) obtained at $4^{\circ}$ for the equilibrium binding of $\left[{ }^{3} \mathrm{H}\right] \mathrm{CD} 367$ to HRPE nuclear extracts. The linearity of the Scatchard plot $(r=0.982, \mathrm{P}<0.0001)$ and computer analysis of the saturation plots indicate the presence of a single class of binding sites. Data shown are from a single representative experiment performed in duplicate.

Figure 6. Competition experiments of Retinoic Acid (RA) and several flavonoids for specific $\left[{ }^{3} \mathrm{H}\right] \mathrm{CD} 363$ binding carried out at $4^{\circ} \mathrm{C}$ on HRPE nuclear extracts. Data shown are from a single representative experiment performed in duplicate. 


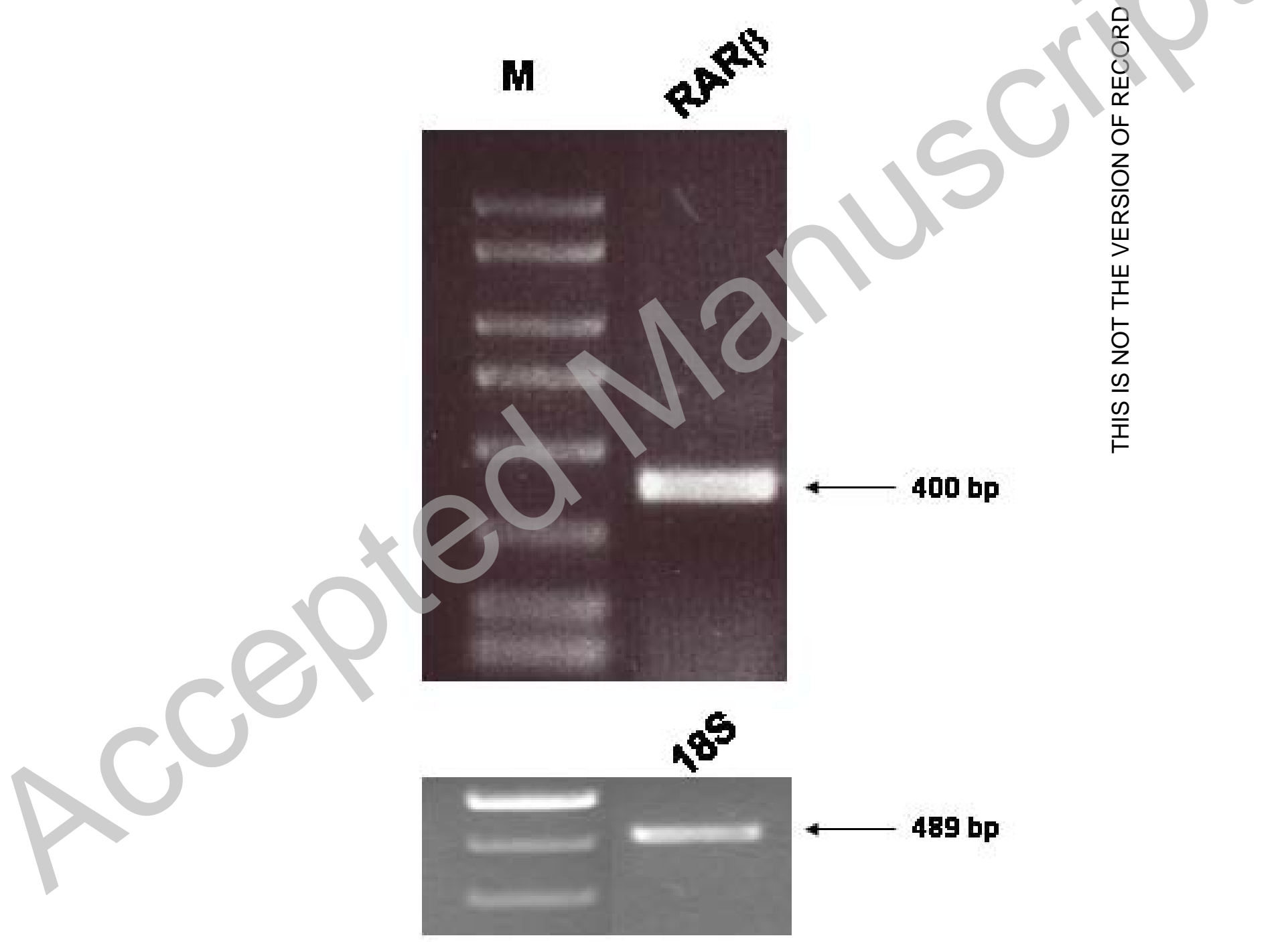

Licenced copy. Copying is not permitted, except with prior permission and as allowed by law.

(C) 2008 The Authors Journal compilation (c) 2008 Biochemical Society 


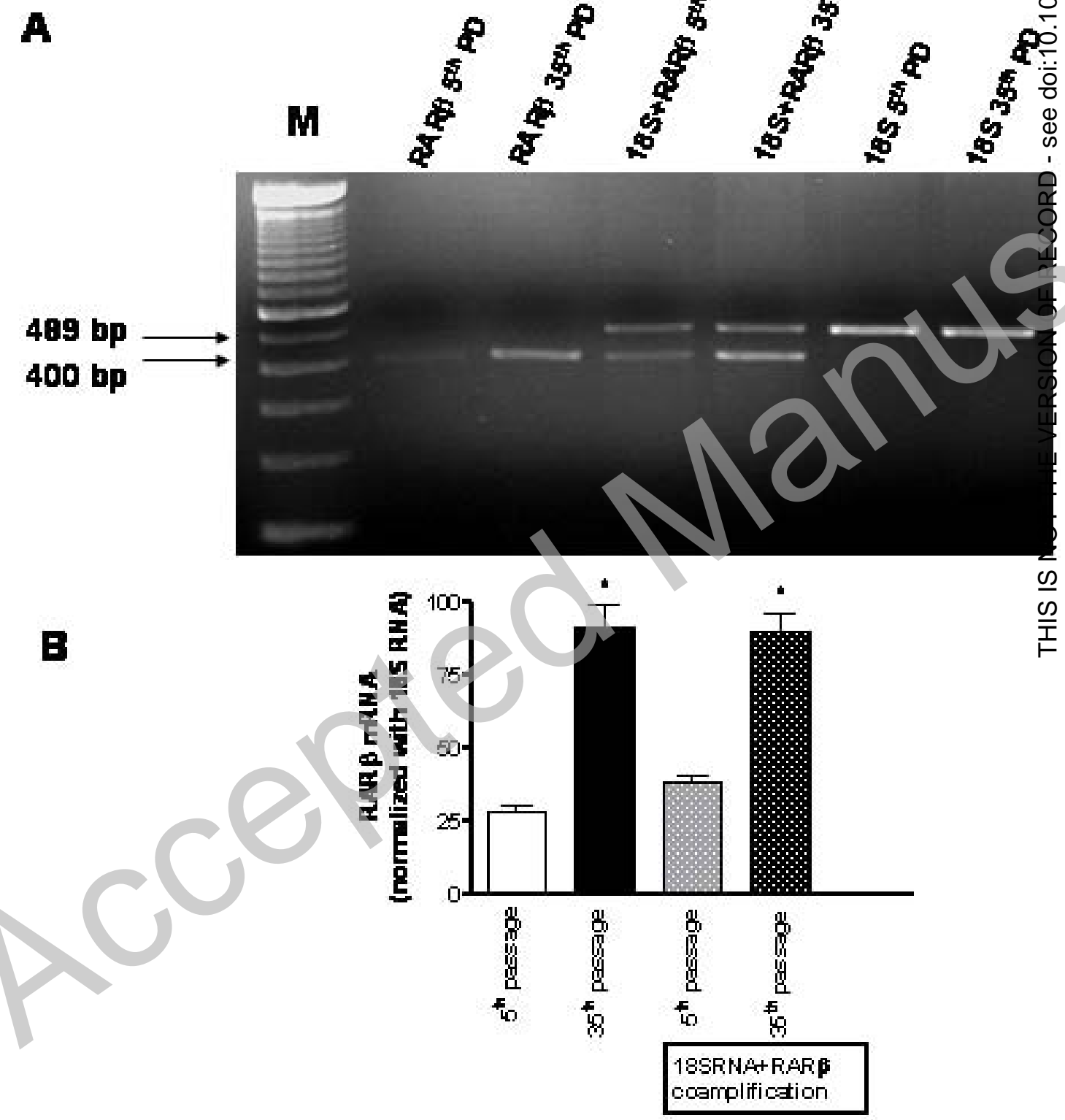




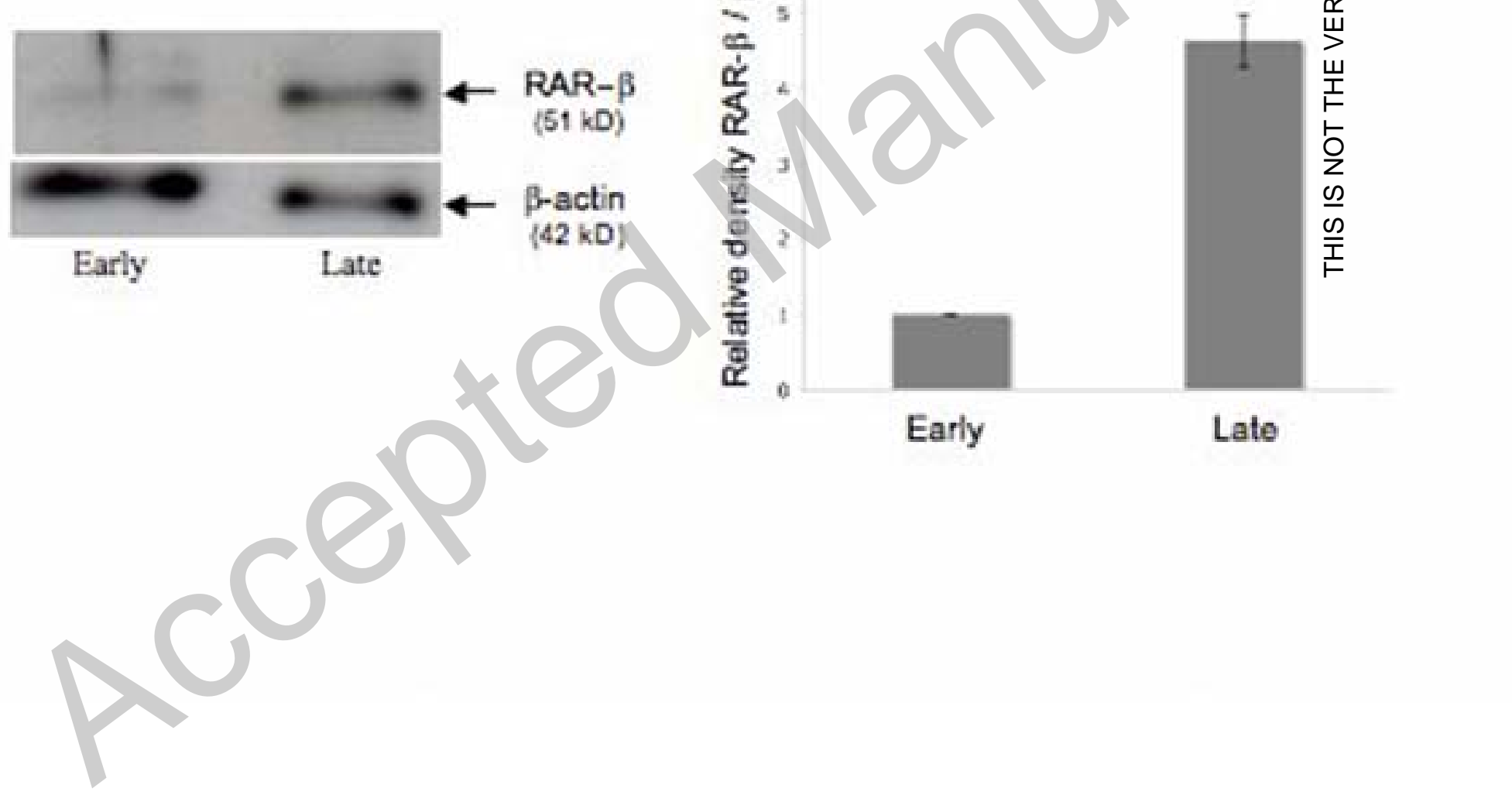

Licenced copy. Copying is not permitted, except with prior permission and as allowed by law. (C) 2008 The Authors Journal compilation (C) 2008 Biochemical Society 


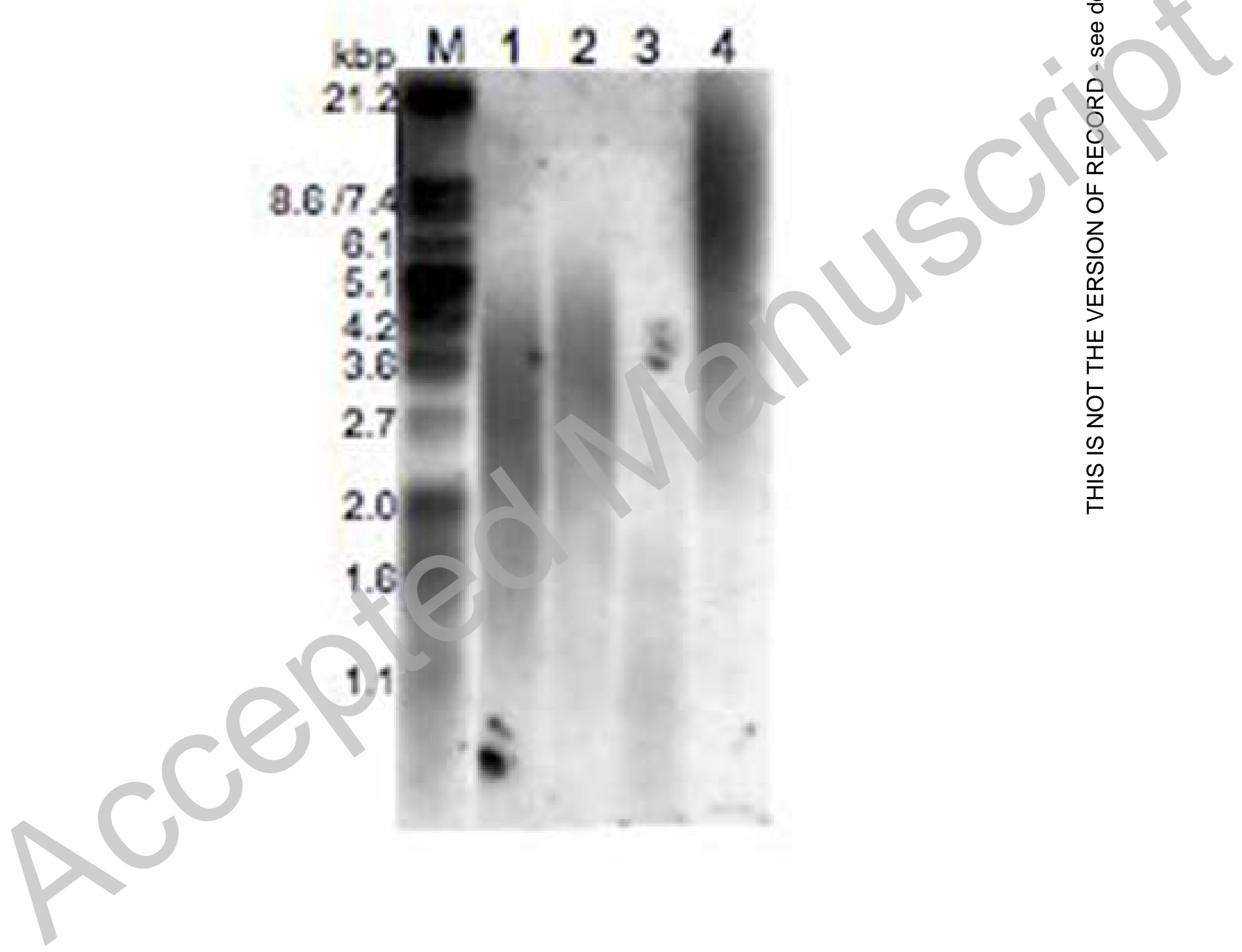

Licenced copy. Copying is not permitted, except with prior permission and as allowed by law. (C) 2008 The Authors Journal compilation (C) 2008 Biochemical Society 


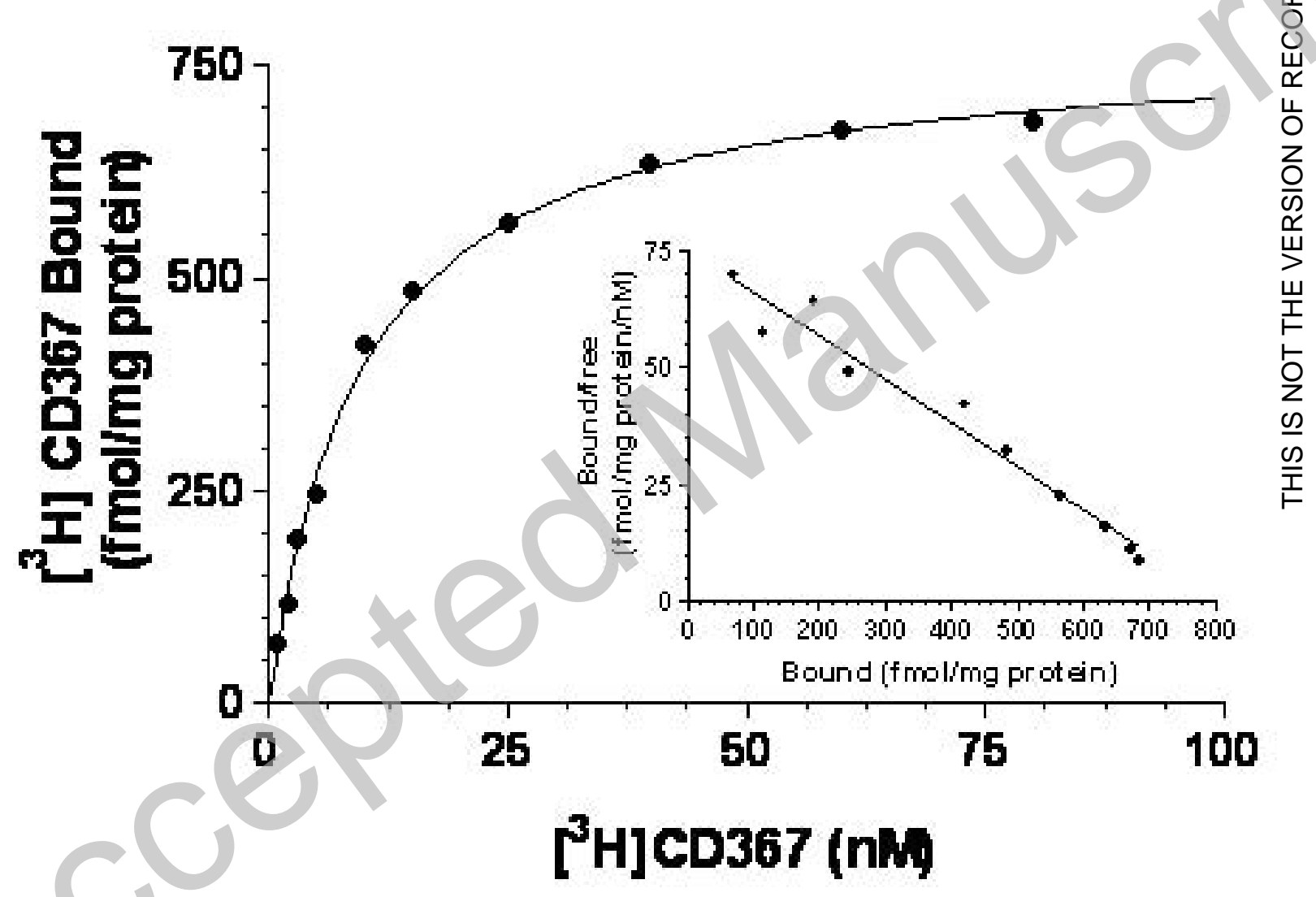

Licenced copy. Copying is not permitted, except with prior permission and as allowed by law.

(C) 2008 The Authors Journal compilation (C) 2008 Biochemical Society 


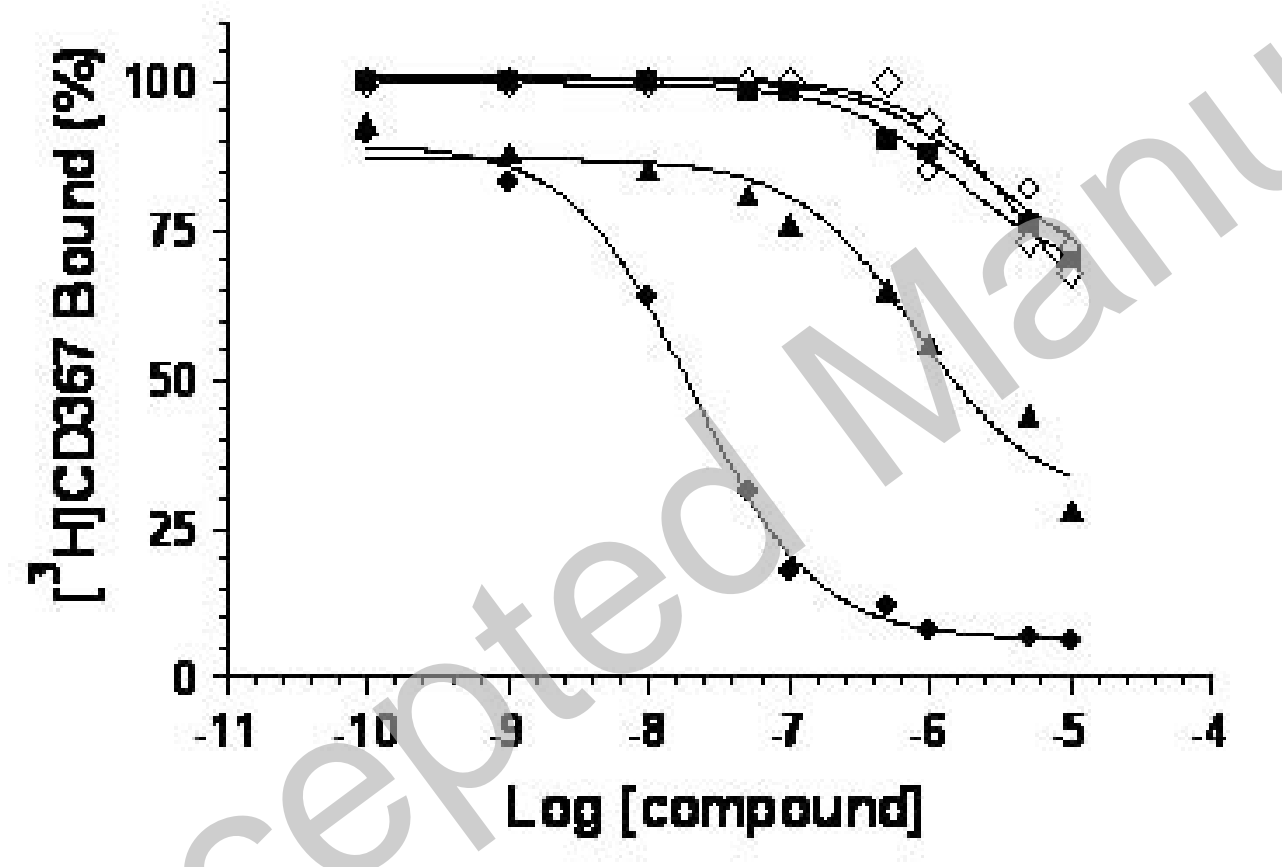

- FA

- Genistei范

$\diamond$ Daidzeir崖

- Quercetīi

- Equol 
Table 1

\begin{tabular}{|c|c|c|c|c|c|c|c|}
\hline Gene & Primer sequences & $\begin{array}{c}\text { Primer } \\
\text { site }\end{array}$ & $\begin{array}{c}\text { Product } \\
\text { length }(\mathrm{bp})\end{array}$ & $\begin{array}{c}\mathrm{Ta} \\
\left({ }^{\circ} \mathrm{C}\right)\end{array}$ & $\begin{array}{l}\mathrm{n}^{\circ} \text { of } \\
\text { cycles }\end{array}$ & $\begin{array}{l}\text { Genbank } \\
\text { acc. no. }\end{array}$ & Ref. \\
\hline$R A R \alpha$ & $\begin{array}{ll}\text { forw. } & \text { 5'-tgc tgg agg cgc taa agg tc-3', } \\
\text { rev. } & 5 \text { '-tct gtc caa gga gtc gct gcc-3' }\end{array}$ & $\begin{array}{l}1519- \\
2012\end{array}$ & 493 & 52 & 32 & NM_000964 & [20] \\
\hline$R A R \beta$ & $\begin{array}{l}\text { forw. } 5 \text { '-tgc ctt tgg aaa tgg atg aca c-3' } \\
\text { rev. } 5 \text { '-tga ctg acc cca ctg ttt tcc-3' }\end{array}$ & $\begin{array}{l}1040- \\
1439\end{array}$ & 399 & 49 & 32 & NM_016152 & [20] \\
\hline$R A R \gamma$ & $\begin{array}{l}\text { forw. } 5 \text { '-ggc tac caa gtg cat cat caa ga-3' } \\
\text { rev. } \quad 5 \text { '-agcaggtcetccecagtcact-3' }\end{array}$ & $932-1691$ & 759 & 52 & 32 & $\frac{M}{728}$ & [20] \\
\hline$R X R \alpha$ & $\begin{array}{l}\text { forw. } 5 \text { '-act gec tga ttg aca agc g-3, } \\
\text { rev. } \quad 5 \text {-aca agc tcc gtc agc acc }-3 \text {, }\end{array}$ & $602-1136$ & 534 & 48 & 30 & 52773 & [14] \\
\hline$R X R \beta$ & $\begin{array}{l}\text { forw. } 5 \text { '-gcc ccc ctg aag atg tga agc c- } 3^{\prime} \\
\text { rev. } \quad 5,- \text { cca tcc cca tcc ttg tcc ttt c-3' }\end{array}$ & $637-983$ & 346 & 52 & & & [14] \\
\hline$R X R \gamma$ & $\begin{array}{ll}\text { forw. } & 5 \text { '-gca gtt cag agg aca tac agc c-3' } \\
\text { rev. } & 5 \text { '-gcc tca ctc tca gct cgc tct c-3' }\end{array}$ & $346-698$ & 352 & 52 & & U38480 & [14] \\
\hline $\begin{array}{l}18 S \\
r R N A\end{array}$ & $\begin{array}{ll}\text { forw. } & 5 \text { '-tca aga acg aaa gtc gga gg-3' } \\
\text { rev. } & 5 \text { '-gga cat cta agg gca tca ca-3' }\end{array}$ & $\begin{array}{l}1025- \\
1513\end{array}$ & 488 & $\overline{50}$ & 24 & NR_003286 & $\S$ \\
\hline
\end{tabular}

Ta $=$ temperature of annealing; $\S=$ designed by ç Ambion Inc., Texas, USA (www.ambion.com) 
Table 2. Inhibitory constants, $K \mathrm{i}(\mathrm{nM})$, for retinoic acid and several flavonoids obtained by displacement of $10 \mathrm{nM}\left[{ }^{3} \mathrm{H}\right] \mathrm{CD} 367$ from RAR $\beta$ of HRPE nuclear extracts. Values \pm SEM are from three independent experiments performed in duplicate. These values represent the mean of three determinations.

\begin{tabular}{cc}
\hline Compound & $\mathbf{K}_{\mathbf{i}}(\mathbf{n M})$ \\
\hline Retinoic acid & $9.3 \pm 0.4$ \\
Genistein & $910 \pm 53$ \\
Daidzein & $15,200 \pm 910$ \\
Quercetin & $24,600 \pm 1,800$ \\
Equol & $32,400 \pm 2,100$ \\
\hline
\end{tabular}

